\title{
Eating out is associated with self-reported food poisoning: a Western Australia population perspective, 1998 to 2009
}

\author{
Christina M Pollard ${ }^{1,2, *}$, Xingqiong Meng ${ }^{1}$, Sophe Williamson ${ }^{2}$, Jim Dodds ${ }^{2}$ and \\ Colin W Binns ${ }^{1}$ \\ ${ }^{1}$ Curtin Health Innovation Research Institute and School of Public Health, Curtin University, Kent Street, \\ GPO Box U1987, Perth, Western Australia 6845, Australia: ${ }^{2}$ Department of Health in Western Australia, \\ Perth, Western Australia, Australia
}

Submitted 2 April 2013: Final revision received 11 June 2013: Accepted 25 July 2013: First published online 4 September 2013

\begin{abstract}
Objective: To explore factors associated with self-reported food poisoning among Western Australian adults between 1998 and 2009.

Design: Data were pooled from four Nutrition Monitoring Surveys Series which included information on suspected food poisoning among Western Australian adults. Descriptive statistics and multinomial regression analyses were used to describe factors associated with self-reported food poisoning, food safety knowledge and behaviours.

Setting: Population of Western Australia estimated to be 2.5 million in 2009.

Subjects: A representative sample of 4494 adults aged between 18 and 64 years. Results: There was no significant change in self-reported food poisoning over time, with about $18 \%$ saying they had suspected food poisoning in the last 6 months. Overall, $2 \cdot 1 \%$ said they had confirmed their food-borne illness with a nurse of doctor. People less than 34 years old, those with a university degree and people who ate meals out on the day prior to the survey (one meal: OR $=1 \cdot 30$, $95 \%$ CI 1.04, 1.62; two meals: OR $=2 \cdot 21,95 \%$ CI $1 \cdot 30,3 \cdot 76)$ were the most likely to report food poisoning. Younger people were also more likely to have their food poisoning confirmed by a health professional. Use of refrigerator thermometers and cool bags for storing food increased significantly between 2004 and 2009.

Conclusions: Findings support the inclusion of food safety advice in dietary recommendations. Food safety and handling education and training is recommended for food businesses, particularly the takeaway food sector, and for consumers. Because food poisoning is reported more often by younger people, food safety education should begin during childhood.
\end{abstract}

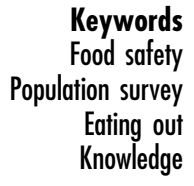

Food-borne illness is a common, costly and preventable public health issue. The true incidence of food-borne disease is difficult to determine as people do not always report it or confirm the diagnosis ${ }^{(1)}$. In Australia, it is estimated that there are 5.4 million cases of food-borne illness each year, costing $\$ A U 1 \cdot 2$ billion annually ${ }^{(2)}$. In 2009, OzFoodNet, the Australian government food-borne disease surveillance network, reported 1820 outbreaks of food-related gastrointestinal illness, affecting 36426 people and causing 118 deaths $^{(2)}$.

Food contamination can occur during food preparation or storage and the risk is reduced with correct food safety handling practices. Most bacterial growth can occur between $5^{\circ} \mathrm{C}$ and $60^{\circ} \mathrm{C}$; therefore, foods that support the growth of food-borne bacteria should be stored at or below $5^{\circ} \mathrm{C}$, or at or above $60^{\circ} \mathrm{C}^{(3)}$. Observational studies have found that consumers store food at temperatures higher than $5^{\circ} \mathrm{C}$, do not wash their hands during food preparation and have poor knowledge of food safety practices $^{(4,5)}$. Basic food safety knowledge helps consumers protect their food from bacterial contamination and food-associated illness ${ }^{(4,5)}$. As well as increasing awareness of the risks of food-borne illness, consumer food safety education should include information about temperature control, correct home food preparation practices and avoiding cross-contamination (including cleaning of refrigeration) ${ }^{(5,6)}$. In Australia, community education programmes have encouraged consumers to keep their domestic refrigerators at a maximum temperature of $4^{\circ} \mathrm{C}$.

Restaurants, cafeterias and other commercial settings are often implicated in food-borne disease outbreaks, with only $20-40 \%$ of food-borne illness accounted for by foods eaten at home in Australia ${ }^{(1)}$. This may be 
due in part to under-reporting of food-borne illness at home. With the increasing trend for eating foods away from home, it is important to monitor foodborne illness and educate the general public and those involved in the food-service sector regarding food safety practices $^{(7)}$

The National Health and Medical Research Council's dietary guidelines advise people to 'Care for your food; prepare and store it safely' ${ }^{\text {(3) }}$. The main causes of foodborne illness in Australia are inadequate cooking; improper holding temperatures; contaminated equipment and/or food storage and preparation areas; contaminated or unsafe raw foods; allowing raw foods to make direct contact with ready-to-eat foods; and poor personal hygiene of food handlers ${ }^{(8,9)}$. Dietary guidelines recommend that we eat more fresh foods and limit consumption of processed foods high in fat, added sugar and salt ${ }^{(3)}$. Some of the foods that consumers are recommended to eat more of are situated within the food groups with higher food safety risk; for example, perishable foods such as fruit, vegetables, dairy products, and lean meats, fish and chicken. Education efforts to improve food safety should focus on personal and kitchen hygiene, refrigeration temperatures, adequate cooking and avoiding cross-contamination ${ }^{(10)}$. Government's response to protecting public health and safety relating to food safety is predominantly through legislation focused at food safety practices or deceptive conduct of food businesses. In addition to this, regulatory agencies have sought to educate consumers about safe food handling ${ }^{(10)}$. The Food Standards Australia New Zealand (FSANZ) Act 1991 sets out the FSANZ's objectives for the development of food standards. In descending order they are to: protect public health and safety; provide adequate information relating to food to enable consumers to make informed choices; and prevent misleading or deceptive conduct of food businesses. Consumer education in Australia is delivered through the FSANZ website, and state and local governments ${ }^{(11)}$. There is also an annual National Food Safety Awareness Week in Australia which provides a focus for food safety messages.

Concern about food-borne illness has been growing over the past few decades, particularly for vulnerable groups such as elderly people ${ }^{(12,13)}$ and younger adults, who have been shown to have poor food handling practices $^{(12)}$. Most research regarding food safety and handling practices and knowledge in Australia and New Zealand have focused on hand washing behaviour ${ }^{(14-17)}$.

There is limited information available on the Western Australian population's knowledge regarding food safety. Understanding and monitoring consumer food safety knowledge and attitudes is useful when developing interventions or actions to improve diet and at the same time reduce the incidence of food-borne illness.

The Health Department of Western Australia's Nutrition Monitor Survey Series (NMSS) has monitored adults' self-reported food poisoning incidence, food safety knowledge, and food purchasing and preparation behaviours since 1998. The NMSS also collects information on the purchase of meals away from home on the day prior to the survey. The present paper explores community trends in self-reported food poisoning and food safety knowledge and behaviours, as well as associated factors, among Western Australian adults between 1998 and 2009.

\section{Experimental methods}

The study was conducted according to the guidelines laid down in the Declaration of Helsinki and all procedures involving human subjects/patients were approved by the Human Research Ethics Committee of the Department of Health in Western Australia (DOHWA HREC; Project number 2011/65) and Research Ethics, Curtin University (SPH-08-2012). Verbal informed consent was obtained from all participants. Verbal consent was witnessed and formally recorded by the telephone interviewers.

\section{Surveys}

The data used for the present analysis were a component of the Western Australia Department of Health's statewide surveys, the NMSS. Food safety questions were asked using computer-assisted telephone interviews of Western Australian adults aged 18 to 64 years, conducted from July to August in 1998, 2001, 2004 and 2009. The 1998, 2001 and 2004 samples were quota sampled by gender and area. The telephone numbers were selected randomly by a computer-generated random digit dialling program. In 2009, the sample was randomly drawn from the 2008 Electronic White Pages for Western Australia and stratified according to area of residence. All sample households with an address were sent a primary approach letter explaining the purpose the survey, how the sample was selected, who would be asked to do the survey and about how long it would take. Every household in the initial sample was called and asked if someone aged 18-64 years was resident and if so, which one had the most recent birthday. No substitutes were accepted.

\section{Measures}

Respondents were asked two food poisoning questions, six about food handling and preparation, and one question about the purchase of meals to be eaten away from home foods on the day prior to the survey. The foodborne illness questions were: 'In the last 6 months have you experienced vomiting and/or diarrhoea, which you suspect may have been food poisoning?'; and then, 'Was the food poisoning positively identified by a doctor or nurse?' The food handling questions were: 'How often do you put your cold or frozen food in an "Esky" [brand name for an ice box cooler] to transport it from the shops to home?'; 'What do you think is the maximum 
temperature a fridge should operate at?'; 'Do you have a thermometer in your main refrigerator at home?'; and 'Do you have any responsibility for doing the food shopping (choosing and preparing meals) in your household?' The number of meals eaten out was derived from the question: "Which meal did you buy from a restaurant, takeaway, lunch bar, canteen, or other prepared food outlet yesterday?' (breakfast, lunch, evening meal, none).

Demographic information collected included age, gender, income, education level, paid employment and country of birth.

\section{Statistical analysis}

The data were collected and weighted to be representative of the Western Australian population. Data for all the years were pooled and weighted to account for sample design and post-adjusted for age, sex and geographic area to a single standard population to allow for comparison over time. The standard population used was the 2006 Estimated Resident Population of Western Australia as it was the most recent census year ${ }^{(18)}$. The SURVEY module of the statistical software program STATA version $12 \cdot 0$ was used for all analyses. Multiple regression analyses explored associations of suspected food poisoning with year of survey, demographic characteristics (age, gender, residential area, education level, household income, employment status, country of birth), takeaway meal consumption, and food preparation and purchasing responsibility. Userdefined simplest models were reported; variables with $P<0.05$ were retained in the model except for 'survey year', which was forced into the final models.

\section{Results}

A total of 4494 adults aged 18-64 years participated in the survey between 1998 and 2009. Demographics of the sample are shown in Table 1.

An average of $18 \%$ of the population reported suspected food poisoning in the 6 months prior to the survey, ranging from $15 \%$ to $19 \%$ across the survey years; however, the differences were not statistically significant $(P=0 \cdot 48)$, see Table 2 . Younger adults aged $18-34$ years were significantly more likely than those over 35 years of age to report suspected food poisoning in 2009 compared with 2001. The proportion of suspected food poisoning cases that were confirmed by a doctor or a nurse was about $2 \%$ overall. This figure represents only $10 \cdot 5 \%$ of those who said they had suspected food poisoning.

Table 1 Sample demographics; Nutrition Monitoring Survey Series, Western Australia, 1998-2009

\begin{tabular}{|c|c|c|c|c|c|}
\hline & $\begin{array}{c}1998 \\
(n 1004)\end{array}$ & $\begin{array}{c}2001 \\
(n+1004)\end{array}$ & $\begin{array}{c}2004 \\
(n+1202)\end{array}$ & $\begin{array}{c}2009 \\
(n 1284)\end{array}$ & $\begin{array}{c}\text { Totalt } \\
(n \text { 4494) }\end{array}$ \\
\hline & $n$ & $n$ & $n$ & $n$ & $\%$ \\
\hline \multicolumn{6}{|l|}{ Sex } \\
\hline Female & 502 & 502 & 601 & 830 & $49 \cdot 2$ \\
\hline Male & 502 & 502 & 601 & 454 & $50 \cdot 8$ \\
\hline \multicolumn{6}{|l|}{ Age group (years) } \\
\hline $18-24$ & 110 & 118 & 103 & 71 & $15 \cdot 8$ \\
\hline $25-34$ & 210 & 245 & 232 & 180 & $21 \cdot 5$ \\
\hline $35-44$ & 305 & 296 & 333 & 340 & $23 \cdot 6$ \\
\hline $45-54$ & 234 & 212 & 297 & 356 & $22 \cdot 2$ \\
\hline $55-64$ & 145 & 133 & 237 & 337 & $16 \cdot 9$ \\
\hline \multicolumn{6}{|l|}{ Area of residence } \\
\hline Metropolitan & 751 & 754 & 601 & 965 & $77 \cdot 9$ \\
\hline Remote areas & 63 & 62 & 150 & 29 & 3.9 \\
\hline Rural areas & 190 & 188 & 451 & 290 & $18 \cdot 2$ \\
\hline \multicolumn{6}{|l|}{ Education } \\
\hline Less than high school & 336 & 303 & 330 & 221 & $28 \cdot 2$ \\
\hline High school & 237 & 265 & 257 & 178 & $25 \cdot 3$ \\
\hline Trade/certificate/diploma & 95 & 77 & 177 & 481 & $11 \cdot 2$ \\
\hline University degree & 336 & 344 & 435 & 399 & $34 \cdot 8$ \\
\hline Missing & 0 & 15 & 3 & 5 & 0.5 \\
\hline \multicolumn{6}{|l|}{ Household income (\$AU) } \\
\hline$\leq 60000$ & 603 & 558 & 603 & 349 & $54 \cdot 5$ \\
\hline$>60000$ & 305 & 340 & 560 & 814 & $36 \cdot 9$ \\
\hline Missing & 96 & 106 & 39 & 121 & $8 \cdot 7$ \\
\hline \multicolumn{6}{|l|}{ Employment } \\
\hline Not in paid employment & 263 & 278 & 285 & 364 & $26 \cdot 3$ \\
\hline Currently in paid employment & 741 & 726 & 917 & 920 & $73 \cdot 7$ \\
\hline \multicolumn{6}{|l|}{ County of birth } \\
\hline Australia & 665 & 668 & 868 & 867 & $67 \cdot 4$ \\
\hline Non-Australian & 339 & 336 & 334 & 416 & $32 \cdot 6$ \\
\hline Missing & 0 & 0 & 0 & 1 & 0 \\
\hline
\end{tabular}

tPercentages were weighted for probability of sample selection and adjusted by age, sex and geographic area to the 2006 Estimated Resident Population of Western Australia. 
Table 2 Proportion of adults reporting food poisoning (suspected and confirmed), takeaway meal consumption, food safety knowledge and food preparation responsibility; Nutrition Monitoring Surveys Series, Western Australia, 1998-2009+

\begin{tabular}{|c|c|c|c|c|c|c|c|c|c|}
\hline & \multicolumn{2}{|c|}{1998} & \multicolumn{2}{|c|}{2001} & \multicolumn{2}{|c|}{2004} & \multicolumn{2}{|c|}{2009} & \multirow[b]{2}{*}{$P$ value } \\
\hline & $\%$ & $95 \% \mathrm{Cl}$ & $\%$ & $95 \% \mathrm{Cl}$ & $\%$ & $95 \% \mathrm{Cl}$ & $\%$ & $95 \% \mathrm{Cl}$ & \\
\hline \multicolumn{10}{|l|}{ Food poisoning } \\
\hline Suspected in last 6 months ( $n$ 4493) & $18 \cdot 3$ & $15 \cdot 9,20 \cdot 9$ & $18 \cdot 8$ & $16 \cdot 4,21 \cdot 4$ & $16 \cdot 8$ & $14 \cdot 4,19 \cdot 5$ & $15 \cdot 0$ & $12 \cdot 9,17 \cdot 3$ & $0 \cdot 48$ \\
\hline Confirmed by a doctor or nurse ( $n$ 4493) & $2 \cdot 1$ & $1 \cdot 4,3 \cdot 3$ & $2 \cdot 3$ & $1 \cdot 5,3 \cdot 5$ & $2 \cdot 0$ & $1 \cdot 2,3 \cdot 3$ & $2 \cdot 6$ & $1 \cdot 7,3 \cdot 9$ & 0.90 \\
\hline If yes, confirmed by a doctor or nurse ( $n$ 748) & $10 \cdot 4$ & $6 \cdot 8,15 \cdot 7$ & $10 \cdot 8$ & $7 \cdot 1,16 \cdot 0$ & $10 \cdot 2$ & $6 \cdot 4,16 \cdot 0$ & $17 \cdot 3$ & $11 \cdot 9,24 \cdot 6$ & $0 \cdot 88$ \\
\hline Ice box cooler usage ( $n$ 2990) & & & & & & & & & $<0.001$ \\
\hline Always & $5 \cdot 2$ & $3 \cdot 9,6 \cdot 9$ & $4 \cdot 9$ & $3 \cdot 7,6 \cdot 6$ & - & - & $17 \cdot 3$ & $15 \cdot 0,19 \cdot 8$ & \\
\hline Usually/most times & $3 \cdot 9$ & $2 \cdot 7,5 \cdot 5$ & $3 \cdot 1$ & $2 \cdot 1,4 \cdot 5$ & - & - & $9 \cdot 6$ & $7 \cdot 6,12 \cdot 0$ & \\
\hline Occasionally & $12 \cdot 3$ & $10 \cdot 1,14 \cdot 8$ & $10 \cdot 2$ & $8 \cdot 3,12 \cdot 4$ & - & - & $16 \cdot 4$ & $14 \cdot 1,18 \cdot 9$ & \\
\hline Never & $78 \cdot 6$ & $75 \cdot 7,81 \cdot 3$ & $81 \cdot 8$ & $79 \cdot 1,84 \cdot 2$ & - & - & $56 \cdot 8$ & $53 \cdot 5,60 \cdot 0$ & \\
\hline Maximum fridge temperature ( $n$ 3292) & & & & & & & & & $0 \cdot 27$ \\
\hline Said they knew & $59 \cdot 6$ & $56 \cdot 5,62 \cdot 7$ & $62 \cdot 1$ & $59 \cdot 0,65 \cdot 1$ & - & - & $62 \cdot 0$ & $58 \cdot 8,65 \cdot 0$ & \\
\hline Said they did not know & $40 \cdot 4$ & $37 \cdot 3,43 \cdot 5$ & $37 \cdot 9$ & $34 \cdot 9,41 \cdot 0$ & - & - & $38 \cdot 0$ & $35 \cdot 0,41 \cdot 2$ & \\
\hline Temperature given ( $n$ 2008) & & & & & & & & & 0.87 \\
\hline Not correct & $65 \cdot 5$ & $61 \cdot 4,69 \cdot 3$ & $65 \cdot 9$ & $62 \cdot 0,69 \cdot 7$ & - & - & $67 \cdot 1$ & $63 \cdot 1,70 \cdot 8$ & \\
\hline Correct $\left(4^{\circ} \mathrm{C}\right)$ & 34.5 & $30 \cdot 7,38 \cdot 6$ & $34 \cdot 1$ & $30 \cdot 3,38 \cdot 0$ & - & - & $32 \cdot 9$ & $29 \cdot 2,36 \cdot 9$ & \\
\hline Thermometer in main fridge $(n$ 3262) & & & & & & & & & 0.006 \\
\hline No & $88 \cdot 9$ & $86 \cdot 7,90 \cdot 8$ & $87 \cdot 3$ & $85 \cdot 0,89 \cdot 3$ & - & - & $70 \cdot 3$ & $67 \cdot 2,73 \cdot 3$ & \\
\hline Yes & $10 \cdot 9$ & $9 \cdot 1,13 \cdot 1$ & $12 \cdot 4$ & $10 \cdot 4,14 \cdot 7$ & - & - & $29 \cdot 7$ & $26 \cdot 7,32 \cdot 8$ & \\
\hline No fridge & $0 \cdot 2$ & $0 \cdot 0,0 \cdot 6$ & $0 \cdot 3$ & $0.1,0.9$ & - & - & 0 & - & \\
\hline Responsibility for food shopping ( $n$ 4494) & & & & & & & & & 0.02 \\
\hline No & $17 \cdot 9$ & $15 \cdot 5,20 \cdot 4$ & $13 \cdot 3$ & $11 \cdot 2,15 \cdot 6$ & $15 \cdot 9$ & $13 \cdot 7,18 \cdot 5$ & $11 \cdot 9$ & $9 \cdot 7,14 \cdot 5$ & \\
\hline Sole responsibility & $45 \cdot 9$ & $42 \cdot 9,49 \cdot 0$ & $51 \cdot 7$ & $48 \cdot 6,54 \cdot 8$ & $46 \cdot 2$ & $43 \cdot 1,49 \cdot 3$ & $45 \cdot 5$ & $42 \cdot 3,48 \cdot 7$ & \\
\hline Shared responsibility & $36 \cdot 2$ & $33 \cdot 2,39 \cdot 3$ & $35 \cdot 0$ & $32 \cdot 1,38 \cdot 1$ & $37 \cdot 9$ & $34 \cdot 8,41 \cdot 0$ & $42 \cdot 6$ & $39 \cdot 5,45 \cdot 8$ & \\
\hline Responsibility for meal preparation ( $n$ 4494) & & & & & & & & & 0.009 \\
\hline No & $11 \cdot 2$ & $9 \cdot 3,13 \cdot 4$ & $9 \cdot 9$ & $8 \cdot 1,11 \cdot 9$ & $11 \cdot 4$ & $9 \cdot 5,13 \cdot 7$ & $9 \cdot 3$ & $7 \cdot 5,11 \cdot 6$ & \\
\hline Sole responsibility & $42 \cdot 6$ & $39 \cdot 6,45 \cdot 6$ & $50 \cdot 8$ & $47 \cdot 7,53 \cdot 9$ & $44 \cdot 4$ & $41 \cdot 3,47 \cdot 5$ & $40 \cdot 8$ & $37 \cdot 8,44 \cdot 0$ & \\
\hline Shared responsibility & $46 \cdot 2$ & $43 \cdot 1,49 \cdot 3$ & $39 \cdot 4$ & $36 \cdot 3,42 \cdot 5$ & $44 \cdot 2$ & $41 \cdot 0,47 \cdot 4$ & $49 \cdot 9$ & $46 \cdot 7,53 \cdot 0$ & \\
\hline Meals eaten out yesterday ( $n$ 4485) & & & & & & & & & $0 \cdot 79$ \\
\hline No & $68 \cdot 3$ & $65 \cdot 3,71 \cdot 2$ & $69 \cdot 9$ & $66 \cdot 9,72 \cdot 7$ & $69 \cdot 7$ & $66 \cdot 6,72 \cdot 7$ & $70 \cdot 2$ & $67 \cdot 2,73 \cdot 1$ & \\
\hline One meal & $28 \cdot 8$ & $26 \cdot 0,31 \cdot 7$ & $27 \cdot 8$ & $25 \cdot 0,30 \cdot 7$ & $27 \cdot 3$ & $24 \cdot 4,30 \cdot 3$ & $28 \cdot 4$ & $25 \cdot 6,31 \cdot 5$ & \\
\hline Two meals & 2.9 & $2 \cdot 0,4 \cdot 3$ & $2 \cdot 3$ & $1 \cdot 5,3 \cdot 5$ & 3.0 & $2 \cdot 0,4 \cdot 5$ & $1 \cdot 3$ & $0.8,2.2$ & \\
\hline
\end{tabular}

tEstimates were weighted for probability of sample selection and adjusted by age, sex and geographic area to the 2006 Estimated Resident Population of Western Australia. $P$ values were derived from a survey design-based Pearson $\chi^{2}$ test. 


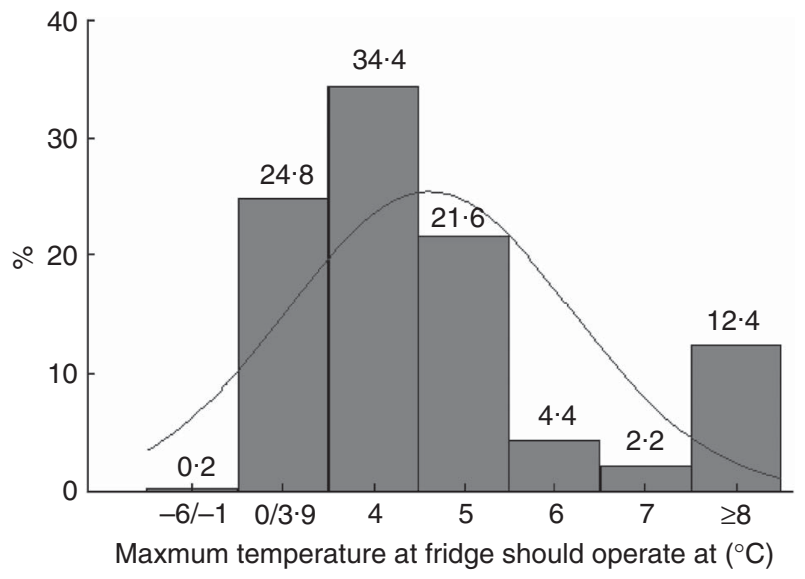

Fig. 1 Maximum temperature a fridge should operate at reported by Western Australian adults aged 18-64 years ( $n$ 2008) who said they knew the temperature; Nutrition Monitoring Surveys Series, 1998, 2001 and 2009

Significantly more people reported using an ice box cooler when transporting cold or frozen food in 2009 (27\%) than in 1998 (9\%) or 2001 (8\%; $P<0 \cdot 001)$. Respondents were also significantly more likely to report having a thermometer in their main fridge in 2009 (30\%) than in $1998(11 \%)$ or $2001(12 \% ; P=0 \cdot 006)$.

Although about $60 \%$ of respondents said they knew the maximum temperature that a refrigerator should operate at, only a third of those who said they knew the temperature gave the correct temperature of $4^{\circ} \mathrm{C}$, and this did not change over time. The correct temperature was specified as $4{ }^{\circ} \mathrm{C}$ (based on $40^{\circ} \mathrm{F}$, the recommended home refrigerator temperature ${ }^{(19)}$; the range of temperatures reported is shown in Fig. 1.

Most people said they had some responsibility (sole or shared) for food shopping, increasing from $82 \%$ in 1998 to $88 \%$ in $2009(P=0.02)$. Similarly, most people, about $90 \%$, had some responsibility for meal preparation, with more people sharing responsibility than having sole responsibility for preparing meals $(P=0 \cdot 009)$. There was no significant difference over time in the proportion of people buying takeaway meals on the day prior to the survey $(P=0 \cdot 79)$.

Logistic regression modelling (Table 3) found no significant difference in the prevalence of self-reported suspected food poisoning (in the 6 months prior the survey) from 1998 to 2009. People less than 35 years old (18-24 years: $\mathrm{OR}=2 \cdot 01,95 \%$ CI $1 \cdot 36,2 \cdot 97 ; 25-34$ years: OR $=2 \cdot 01,95 \%$ CI $1 \cdot 44,2 \cdot 82)$, those with a university education $(\mathrm{OR}=1 \cdot 29,95 \% \mathrm{CI} 1 \cdot 05,1 \cdot 58)$ and those who had purchased takeaway meal/s on the day prior to the survey (one meal: $\mathrm{OR}=1 \cdot 32,95 \%$ CI 1.06, 1.64; two meals: $\mathrm{OR}=2 \cdot 37,95 \%$ CI $1 \cdot 40,4 \cdot 03)$ were significantly more likely to say they had suspected food poisoning. People who were younger were significantly more likely to report that their food poisoning was confirmed by a doctor or nurse $(18-24$ years: $\mathrm{OR}=4 \cdot 25,95 \%$ CI $1 \cdot 46$, 12.36; 24-34 years: OR $=3 \cdot 81,95 \%$ CI $1 \cdot 42,10 \cdot 24)$ with no difference across survey years. Those people living in rural Western Australia were significantly less likely to report either suspected or confirmed food poisoning.

Men were 2.3 times more likely than women to say they knew the maximum temperature for a refrigerator $(\mathrm{OR}=2 \cdot 34,95 \% \mathrm{CI} 1 \cdot 71,3 \cdot 21)$, as were people with a university education $(\mathrm{OR}=1 \cdot 88,95 \% \mathrm{CI} 1 \cdot 35,2 \cdot 63)$ and those currently in paid employment (OR $=1 \cdot 51,95 \% \mathrm{CI}$ $1 \cdot 06,2 \cdot 13$ ). However, being male ( $\mathrm{OR}=1 \cdot 55$, 95\% CI $1 \cdot 10,2 \cdot 18)$ was the only significant predictor for giving a correct answer for the maximum refrigerator temperature.

In 2009 , people were $3 \cdot 4$ times more likely to report having a thermometer in their main fridge than they were in $1998(\mathrm{OR}=3 \cdot 40,95 \% \mathrm{CI} 2 \cdot 27,5 \cdot 10)$.

\section{Discussion}

Overall, there has been no significant increase in the incidence of self-reported suspected food poisoning since 1998 in Western Australia. Almost one in five people said they had suspected food poisoning in the 6 months prior to the survey and of these, only 10-17\% had confirmed their illness with a health professional. OzFoodNet estimated that $25 \%$ of the population had suspected food poisoning in $2009^{(2)}$, which is consistent with our finding of $18 \%$ of the population reporting suspected food poisoning in the previous 6 months in the present study.

Reliance on confirmed cases of food poisoning underestimates the real incidence and cost of food poisoning for the community. In 2009, the OzFoodNet reported that only $0 \cdot 12 \%$ food poisoning cases were confirmed annually with identification of the specific micro-organism ${ }^{(2)}$ compared with the $2.0 \%$ in the present study, where the confirmation is by a nurse or doctor.

Adults aged less than 35 years were significantly more likely to report suspected food poisoning in the last 6 months. These findings are consistent with previous studies by the Food and Drug Administration in the USA, which found that people aged 18-39 years were more likely than other age groups to believe that they had experienced a food-borne illness ${ }^{(20)}$. This is also the group most likely to report risky food handling and consumption behaviours ${ }^{(21)}$.

Those people who ate takeaway meals twice on the day before the survey were almost three times more likely than those who ate none to have had suspected food poisoning in the last 6 months. Those who ate only one takeaway the day before were $1 \cdot 3$ times as likely to get food-borne illness compared with those who ate none. Previous research has found that restaurants, cafeterias and other commercial settings are frequently implicated in reported food-borne disease outbreaks, while illness from food eaten in the home accounts for $20-40 \%$ of 
Table 3 Factors associated with self-reported suspected and/or confirmed food poisoning and food safety knowledge; Nutrition Monitoring Surveys Series, Western Australia, 1998-2009

\begin{tabular}{|c|c|c|c|c|c|c|c|c|c|c|}
\hline & \multicolumn{2}{|c|}{$\begin{array}{l}\text { Suspected food } \\
\text { poisoning in last } \\
6 \text { months } \\
(n 4461)\end{array}$} & \multicolumn{2}{|c|}{$\begin{array}{l}\text { Food poisoning } \\
\text { confirmed by a } \\
\text { doctor or nurse } \\
\quad(n 4461)\end{array}$} & \multicolumn{2}{|c|}{$\begin{array}{l}\text { Said they knew the } \\
\text { maximum fridge } \\
\text { temperature } \\
(n 3272) \dagger\end{array}$} & \multicolumn{2}{|c|}{$\begin{array}{c}\text { Gave correct fridge } \\
\text { temperature } \\
(n 3272) \dagger\end{array}$} & \multicolumn{2}{|c|}{$\begin{array}{c}\text { Have a fridge } \\
\text { thermometer } \\
(n 3262) \dagger\end{array}$} \\
\hline & OR & $95 \% \mathrm{Cl}$ & OR & $95 \% \mathrm{Cl}$ & OR & $95 \% \mathrm{Cl}$ & OR & $95 \% \mathrm{Cl}$ & OR & $95 \% \mathrm{Cl}$ \\
\hline \multicolumn{11}{|l|}{ Year of survey (Ref. $1998(\mathrm{OR}=1 \cdot 00)$ ) } \\
\hline 2001 & $1 \cdot 01$ & $0 \cdot 80,1 \cdot 28$ & 0.99 & $0.52,1 \cdot 87$ & $1 \cdot 12$ & $0 \cdot 82,1 \cdot 53$ & 1.03 & $0.73,1.47$ & $1 \cdot 18$ & $0 \cdot 75,1 \cdot 84$ \\
\hline 2004 & 0.91 & $0 \cdot 71,1 \cdot 17$ & 0.97 & $0.49,1.92$ & \multicolumn{2}{|r|}{ NA } & \multicolumn{2}{|r|}{ NA } & \multicolumn{2}{|r|}{ NA } \\
\hline 2009 & 0.86 & $0 \cdot 67,1 \cdot 10$ & $1 \cdot 46$ & $0 \cdot 78,2 \cdot 72$ & $1 \cdot 28$ & $0.94,1.75$ & 1.05 & $0.74,1.51$ & $3 \cdot 40$ & $2 \cdot 27,5 \cdot 10^{\star \star \star}$ \\
\hline \multicolumn{11}{|l|}{ Age (years) (Ref. 55-64 years ref $(O R=1 \cdot 00))$} \\
\hline $18-24$ & $2 \cdot 01$ & $1 \cdot 36,2 \cdot 97^{\star \star \star}$ & $4 \cdot 25$ & $1 \cdot 46,12 \cdot 36^{\star \star}$ & \multirow{2}{*}{\multicolumn{2}{|c|}{-}} & \multicolumn{2}{|r|}{-} & \multicolumn{2}{|r|}{-} \\
\hline $25-34$ & $2 \cdot 01$ & $1 \cdot 44,2 \cdot 82^{\star \star \star}$ & $3 \cdot 81$ & $1 \cdot 42,10 \cdot 24^{\star \star}$ & & & \multirow{2}{*}{\multicolumn{2}{|c|}{-}} & \multirow{2}{*}{\multicolumn{2}{|c|}{-}} \\
\hline $35-44$ & $1 \cdot 21$ & $0.87,1.69$ & $1 \cdot 76$ & $0 \cdot 65,4 \cdot 79$ & \multicolumn{2}{|r|}{-} & & & & \\
\hline $45-54$ & 1.09 & $0.77,1.56$ & 0.73 & $0 \cdot 19,2 \cdot 75$ & \multicolumn{2}{|r|}{-} & \multicolumn{2}{|r|}{-} & \multicolumn{2}{|r|}{ _ } \\
\hline \multicolumn{11}{|l|}{ Sex $($ Ref. male $(O R=1 \cdot 00))$} \\
\hline Female & \multicolumn{2}{|c|}{-} & \multicolumn{2}{|r|}{-} & $2 \cdot 34$ & $1 \cdot 71,3 \cdot 21^{\star * *}$ & \multirow{2}{*}{\multicolumn{2}{|c|}{$1 \cdot 10,2 \cdot 18^{*}$}} & \multicolumn{2}{|r|}{ _- } \\
\hline \multicolumn{9}{|l|}{$\begin{array}{l}\text { Education (Ref. less than university degree } \\
(\mathrm{OR}=1.00))\end{array}$} & & \\
\hline University degree & $1 \cdot 29$ & $1 \cdot 05,1 \cdot 58^{*}$ & & - & $1 \cdot 88$ & $1 \cdot 35,2 \cdot 63^{\star \star \star}$ & \multirow{2}{*}{\multicolumn{2}{|c|}{-}} & \multicolumn{2}{|r|}{-} \\
\hline \multicolumn{9}{|l|}{ Paid employment (Ref. not employed $(\mathrm{OR}=1 \cdot 00)$ ) } & & \\
\hline In paid employment & \multirow{2}{*}{\multicolumn{2}{|c|}{-}} & \multicolumn{2}{|r|}{-} & \multirow{2}{*}{\multicolumn{2}{|c|}{$1 \cdot 06,2 \cdot 13^{\star}$}} & \multirow{2}{*}{\multicolumn{2}{|c|}{-}} & & - \\
\hline Residential area (Ref. metropolitan $(\mathrm{OR}=1.00)$ & & & & & & & & & & \\
\hline Remote & 0.89 & $0.63,1.26$ & $0 \cdot 88$ & $0.38,2 \cdot 02$ & & - & & - & & - \\
\hline Rural & 0.67 & $0.53,0.86^{\star \star \star}$ & 0.50 & $0.25,1 \cdot 00^{*}$ & & - & & - & & - \\
\hline Meals eaten out yesterday (Ref. none $(\mathrm{OR}=1 \cdot 00)$ ) & & & & & & & & & & \\
\hline One meal & $1 \cdot 32$ & $1 \cdot 06,1 \cdot 64^{\star}$ & & - & & - & & _- & & - \\
\hline Two meals & $2 \cdot 37$ & $1 \cdot 40,4 \cdot 03^{\star \star \star}$ & & - & & - & & - & & - \\
\hline
\end{tabular}

Ref., reference group; NA, data not available.

tData not available for 2004. Results were derived from logistic regression analyses using the SURVEY module and user-defined simplest models are reported: only variables with $P<0.05$ were retained and reported, except for 'survey year' which was forced into the final model. The full model included demographics (sex, age group, education, income, employment status, country of birth) and associated dietary behaviours (food shopping and preparation responsibility, purchase of meals away from home on day prior to the survey). 
food-borne infection ${ }^{(1)}$. These results support previous US findings suggesting an urgent need to focus on preventing food-borne disease transmission within the food-service industry ${ }^{(22)}$.

Those people living in rural Western Australia were significantly less likely to report either suspected or confirmed food poisoning. This may be because $75 \%$ of the population resides in the metropolitan area in Western Australia; however, the reason for this is unknown and warrants further investigation.

These results highlight the need for further research into the reason why people who eat meals away from home suffer greater food-borne illness. This association could be due to food contamination/improper handing at the restaurant or afterwards, when the consumer has 'taken the food away', highlighting the need for both food safety training for the food-service sector and consumer education regarding reheating or storing takeaway foods.

The findings of the present study highlight the need for community-wide food safety education. Almost everyone in the population has some responsibility for the purchasing or preparation of food for their household. As young people appear to suffer a disproportionate amount of food-borne illness there may be some benefit in targeting food safety education to adolescents and young adults. OzFoodNet reports that travellers acquiring food-borne illness overseas represent a proportion of reported food-borne in Australia ${ }^{(2)}$.

About a third of Western Australian adults reported eating meals away from home on the day prior to the survey. In line with findings of a review of food contamination in ready-to-eat products in retail and food-service environments $^{(7)}$, food safety education and training to retail and food-service managers and food handlers is important to reinforce the need for safe food handling and preparation practices within the food-service sector.

Although many people said they knew the maximum refrigerator temperature, less than half gave the correct value, highlighting the ongoing need to educate consumers about food safety. These findings are consistent with previous research which found that up to $95 \%$ of consumers did not know correct refrigeration temperatures and surveys reporting actual temperature to exceed recommended ranges by up to $70 \%{ }^{(1)}$. It is important that the public continue to be educated regarding temperature control of food prepared at home ${ }^{(6)}$, as well as on personal hygiene, food preparation and storage, and avoiding crosscontamination $^{(23)}$. Manufacturing changes are likely to account for the increased use of refrigerator thermometers as newer models in Australia come with in-built thermometers, so the consumer does not have to take action to purchase one. This simple industry innovation has increased the potential for safer food. The increased availability of cold storage bags available for purchase at grocery stores and specialty food stores may also account for their increased use seen in the present study.
The present study of cross-sectional surveys provides useful insights into changes in population perceptions of suspected food poisoning, food safety and handling knowledge and behaviours over time and within particular sociodemographic groups; but as with all cross-sectional studies, no causality can be attributed to the results. The main limitation of the study is that the way in which the data were collected changed over time (random digit dialling with and without matching to known operational numbers prior to 2009 and Electronic White Pages in 2009). This affected the response rates, which were lower in years when random digit dialling was done without any matching to known operational numbers. The quota sampling in years prior to 2009 also contributed to difficulties in making the population groups comparable. However, weighting as described in the methods section was used to adjust for these sampling differences. Mobile phones were not included in the sample frames prior to 2009; however, in 2004, the time of the previous survey, Australia still relied predominantly on landlines and so bias, if any exists, should be minimal.

Future research is needed to identify the specific attitudes and knowledge limiting safe food handling practices by consumers and the food industry, particularly those people operating food-service businesses. It would be useful to explore food safety knowledge, practices and food poisoning experiences among young adults to help develop effective health promotion interventions. The present study again highlighted the low reporting and confirming of suspected food poisoning. Exploring the barriers to reporting food poisoning is important encourage those suffering food-borne illness to report their case.

\section{Conclusions}

Our findings support the inclusion of food safety advice in dietary guidelines. Food safety and handling education and training is recommended for both food businesses, particularly those preparing meals to be eaten away from home, and for consumers. Because the incidence of food poisoning is significantly higher in younger people, food safety education should begin during childhood.

\section{Acknowledgments}

Sources of funding: The Department of Health in Western Australia had funded and conducted the Nutrition Monitoring Survey Series since 1995. Healthway (the Western Australian Health Promotion Foundation) funded Curtin University's Food Law, Policy and Communications to Improve Public Health Project to assist the translation of research into practice. The funders had no input into the preparation of the manuscript. Conflicts of interest: Nil to declare. Authors' contributions: C.M.P. was involved in managing and developing the NMSS survey 
instruments and worked with the Department of Health in Western Australia to oversee the surveys being conducted. X.M. conducted the statistical analysis and drafted the interpretation of results for the paper. C.M.P. and X.M. wrote the first draft of the paper. S.W., J.D. and C.W.B. contributed to writing the manuscript and agree with the manuscript results and conclusions.

\section{References}

1. Redmond EC \& Griffith CJ (2003) Consumer food handling in the home: a review of food safety studies. J Food Protect 66, 130-161.

2. The OzFoodNet Working Group (2010) Monitoring the incidence and causes of disease potentially transmitted by food in Australia: annual report of the OzFoodNet network, 2009. Commun Dis Intell Q Rep 34, 396-426.

3. Australian Government (2013) Eat for Health. Australian Dietary Guidelines. Providing the Scientific Evidence for Healthier Australian Diets. Canberra: Commonwealth of Australia.

4. Kennedy J, Jackson V, Blair IS et al. (2005) Food safety knowledge of consumers and the microbiological and temperature status of their refrigerators. J Food Protect 68, $1421-1430$

5. Wilcock A, Pun M, Khanona J et al. (2004) Consumer attitudes, knowledge and behaviour: a review of food safety issues. Trends Food Sci Technol 15, 56-66.

6. Jackson V, Blair IS, McDowell DA et al. (2007) The incidence of significant foodborne pathogens in domestic refrigerators. Food Control 18, 346-351.

7. Lianou A \& Sofos JN (2007) A review of the incidence and transmission of Listeria monocytogenes in ready-to-eat products in retail and food service environments. J Food Protect 70, 2172-2198.

8. Crerar SK, Dalton CB, Longbottom HM et al. (1996) Foodborne disease: current trends and future surveillance needs in Australia. Med J Aust 165, 672-675.

9. Redmond EC \& Griffith CJ (2009) The importance of hygiene in the domestic kitchen: implications for preparation and storage of food and infant formula. Perspect Public Health 129, 69-76.
10. Woteki CE \& Kineman BD (2003) Challenges and approaches to reducing foodborne illness. Annu Rev Nutr 23, 315-344.

11. Food Standards Australia New Zealand (2013) Consumer. http://www.foodstandards.gov.au/consumer/Pages/default. aspx (accessed August 2013).

12. Almanza BA, Namkung Y, Ismail JA et al. (2007) Clients' safe food-handling knowledge and risk behavior in a homedelivered meal program. J Am Diet Assoc 107, 816-821.

13. Kendall PA, Hillers VV \& Medeiros LC (2006) Food safety guidance for older adults. Clin Infect Dis 42, 1298-1304.

14. Fischler GE, Fuls JL, Dail EW et al. (2007) Effect of hand wash agents on controlling the transmission of pathogenic bacteria from hands to food. $J$ Food Protect 70, 2873-2877.

15. Jay LS, Comar D \& Govenlock LD (1999) A video study of Australian domestic food-handling practices. J Food Protect 62, 1285-1296.

16. Jay LS, Comar D \& Govenlock LD (1999) A national Australian food safety telephone survey. J Food Protect 62, 921-928.

17. Buchtmann L (2012) Australian men and young adults rate badly in Food Safety Report Card - Food Safety Week 12-17 November 2007. http://www.foodsafety.asn. au/archived-releases/australian-men-and-young-adults-ratebadly-in-food-safety-report-card-food-safety-week-12-17november-2007/ (accessed August 2013)

18. Australian Bureau of Statistics (2011) Table 55: Estimated Resident Population by Single Year of Age, Western Australia. In Australian Demographic Statistics. ABS Catalogue number 3101.O. Canberra: ABS.

19. Albrecht JA \& Larvick C (2007) Refrigerator practices of participants in the meals on wheels program. Food Protect Trends 27, 672-677.

20. Fein SB, Lando AM, Levy AS et al. (2011) Trends in U.S. consumers' safe handling and consumption of food and their risk perceptions, 1988 through 2010. J Food Protect 74, 1513-1523.

21. Altekruse SF, Yang S, Timbo BB et al. (1999) A multi-state survey of consumer food-handling and food-consumption practices. Am J Prev Med 16, 216-221.

22. Jones TF \& Angulo FJ (2006) Eating in restaurants: a risk factor for foodborne disease? Clin Infect Dis 43, 1324-1328.

23. Medeiros LC, Hillers CN, Kendall PA et al. (2001) Food safety education: what should we be teaching to consumers? J Nutr Educ 33, 108-113. 